\title{
Efektivitas Penggunaan Terapi Akupunktur Metode Korean Hand Therapy pada Lansia dengan Nyeri Muskuloskeletal di Posyandu Lansia Poltekkes Kemenkes Surakarta
}

\author{
Joko Tri Haryanto $^{1^{*}}$, Listina Ade Widya Ningtyas ${ }^{2}$ \\ Poltekkes Kemenkes Surakarta Jurusan Akupuntur \\ *Email: atengjoko@gmail.com
}

\begin{abstract}
Background: Disorders of the musculoskeletal system can affect the functions of the body's movers consisting of bones, muscles, cartilage, tendons, ligaments and other connective tissue. Acupuncture therapy began to develop with various types of micro acupuncture that began to be widely applied, such as the Korean Hand Therapy technique. The purpose of this study was to analyze the effectiveness of acupuncture methods or techniques in elderly patients who experience musculoskeletal pain. Methods: This type of research is Quasi Experimental. The location of the study was at the Posyandu Elderly Ngemplak Boyolali in March-May 2019. The population is elderly musculoskeletal pain by 50 people. A sample of 30 people was divided into 3 treatment groups. Data analysis using the Anova Test. Results: Significance results $>0.05$ so it can be concluded that Ho is accepted, Ha is rejected, meaning there is no difference in the method of therapy in reducing pain. Conclusion: The Most Effective Method for Overcoming Musculoskeletal Pain in this Study There was no difference between the Acupuncture Therapy Group, the Korean Hand Therapy Group and the Combined Acupuncture Therapy Group and the Korean Hand therapy.
\end{abstract}

Keywords: acupuncture therapy, korean hand therapy, musculoskeletal pain

\section{PENDAHULUAN}

Nyeri menjadi salah satu respon sensorik dan emosional yang mengganggu seseorang dalam melakukan aktivitas yang disebabkan suatu jaringan mengalami kerusakan bersifat aktual maupun potensial. Salah satu nyeri yang sering terjadi adalah gangguan pada muskuloskeletal yang merupakan salah satu penyebab utama morbiditas yang memiliki pengaruh besar pada kesehatan dan kualitas hidup serta menyebabkan adanya pengeluaran untuk pengobatan. Berbagai macam nyeri muskuloskeletal dapat disebabkan lebih dari 150 penyakit dan sindrom diantaranya penyakit sendi, kelainan tulang belakang trauma (Woolf, 2012).
Penelitian lain yang dilakukan Veerapen et al (2007) di Malaysia dari total populasi 2.594 orang yang diwawancarai $21,1 \%$ memiliki keluhan rematik, nyeri lebih banyak ditemui pada wanita $23,8 \%$ sedangkan pada pria $17,8 \%$. Dalam studi populasi $14,4 \%$ mengeluh nyeri pada persendian dan muskuloskeletal, $\quad 11,6 \%$ mengalami nyeri punggung bawah, dan $64,8 \%$ nyeri lutut. Selain itu adanya gangguan pada sistem muskuloskeletal didalam tubuh manusia dapat mempengaruhi fungsi penggerak tubuh yang terdiri dari tulang, otot, tulang rawan, tendon, ligamen dan jaringan ikat lainnya (Matzkin dan Paci, 2014).

Pasien dengan keluhan nyeri akan berkunjung ke pelayanan kesehatan yang ada untuk mengatasi 
nyeri meliputi terapi fisik, operasi syaraf dan tulang, maupun pengobatan dari dokter (Hofstede et al., 2013). Selain itu terapi yang berkembang di masyarakat sangat beragam, yaitu terapi pengobatan komplementer, alternative dan jamu. Terapi pengobatan komplementer berupa terapi akupunktur, Transcutaneous Electrical Nerve Stimulation (TENS), massage dan reflexology. Terapi akupunktur dapat menjadi salah satu terapi alternatif untuk mengurangi intensitas nyeri yang dirasakan pasien dan meningkatkan kualitas hidupnya, meskipun proses penyembuhannya perlahan (Abdulla et al., 2013). Terapi akupunktur yang paling sering digunakan dalam klinik salah satunya pada sistem musculoskeletal yang dapat diaplikasi pada kasus osteoarthritis, sprain ankle, frozen shoulder, low back pain, myalgia dan lain sebagainya. Prinsip kerja dari terapi akupunktur pada kasus tersebut untuk mereleksasi jaringan musculoskeletal yang mengalami cidera atau trauma (Peilin, 2011).

Berdasarkan berbagai jenis mikro akupunktur tersebut, peneliti tertarik untuk melakukan penelitian terkait penggunaan teknik Korean Hand Therapy pada berbagai kasus nyeri yang ada pada masyarakat lansia. Tujuan penelitian untuk menganalisa efektivitas penggunaan terapi akupunktur metode korean hand therapy pada lansia dengan nyeri muskuloskeletal di posyandu lansia.

\section{METODE PENELITIAN}

Jenis penelitian ini adalah eksperimental dengan rancangan penelitian Quasi Experimental. Desain ini melibatkan tiga kelompok, kelompok pertama diberi perlakuan berupa terapi akupunktur, kelompok kedua berupa terapi Korean Hand Therapy dan kelompok ketiga diberikan perlakuan terapi akupunktur kombinasi Korean Hand Therapy. Pada desain penelitian ini akan menguji efek dari suatu perlakuan terhadap variabel dependen, dengan cara membandingkan variabel dependen pada tiga kelompok eksperimen sebelum dan setelah dikenai perlakuan. Besar sample pada penelitian ini adalah 30 orang, dengan kriteria inklusi yaitu jenis kelamin laki-laki dan perempuan; usia 30 tahun keatas ; nyeri muskuloskeletal lebih dari 1 bulan ; tidak mengkonsumsi Obat ; tidak sedang menderita penyakit kronis; tidak sedang melakukan terapi modalitas lainnya, sedangkan kriteria eksklusi yaitu tidak mengikuti terapi selama 1 bulan ; tidak melakukan pengukuran di akhir evaluasi ; pasien yang mengalami fraktur tulang; pasien dengan kelainan anatomis tulang. Instrumen pengukur nyeri menggunakan Visual Analogue Rating Scale (VAS). Waktu pelaksanaan penelitian selama 6 bulan dengan pelaksanaan pengambilan data frekuensi terapi 3 hari sekali, analisis data menggunakan uji Anova. Penelitian ini dilakukan pada bulan Januari-Juli 2019 di Posyandu Lansia Ngemplak Boyolali.

\section{HASIL PENELITIAN}

Distribusi subyek penelitian berdasarkan Usia menunjukkan usia terendah 31 tahun dan tertinggi 70 tahun. Berdasarkan hasil pengolahan data responden pada Kelompok I, II dan III didapatkan usia responden paling banyak pada usia pertengahan yaitu antara 45-59 tahun sebanyak 18 responden yang mengalami nyeri 
musculoskeletal. Pada usia pertengahan kondisi tubuh akan mengalami degenerative yang menyebabkan mobilitas terganggu. Secara fisiologis bertambahnya umur seseorang dimana terjadi proses degenerative dapat menyebabkan aliran darah ke otot berkurang. Dengan adanya proses degenaratif tersebut jumlah ketersediaan oksigen, nutrisi, dan energi untuk otot menurun dan kekuatan otot manusia berkurang (Brunner \& Sudarth, 2002).

Distribusi sample penelitian berdasarkan Jenis Kelamin didapatkan data distribusi responden penelitian yaitu jenis kelamin laki-laki $30 \%$ dan perempuan $70 \%$. Distribusi sample penelitian berdasarkan Jenis Keluhan terdiri dari nyeri bahu, nyeri lutut, nyeri pinggang, nyeri tumit dan nyeri betis. Dari hasil pengolahan data keluhan terbanyak pada responden dengan keluhan utama nyeri lutut. Nyeri pada lutut sangat berhubungan erat dengan adanya penurunan cairan pada tendon dan tulang, yang diakibatkan tekanan berlebihan pada jaringan tersebut. Akibatnya kondisi ini akan mengakibatkan kaku, bengkak dan meradang (Arovah, 2010).

Distribusi subyek penelitian berdasarkan Visual Analoge Scale Sebelum terapi. Berdasarkan data pada Kelompok I Terapi Akupunktur nilai maksimum sebelum dilakukan tindakan memiliki skala nyeri sebagai berikut skala 5 sebanyak 5 responden $(50 \%)$ dan nilai terendah dengan skala 10 sebanyak 1 responden (10\%). Berdasarkan data pada Kelompok II Korean Hand Therapy nilai maksimum sebelum dilakukan terapi memiliki skala nyeri sebagai berikut skala 5 sebanyak 5 responden $(50 \%)$ dan nilai terendah skala 7 sebanyak 2 responden
(20\%). Berdasarkan data pada Kelompok III Kombinasi Terapi Akupunktur dan Korean Hand Therapy nilai maksimum sebelum diberikan terapi memiliki skala nyeri sebagai berikut skala 5 sebanyak 4 responden (40\%), nilai terendah pada skala 10 sebanyak 1 responden (10\%), skala 9 sebanyak 1 responden (10\%), skala 6 sebanyak 1 responden $(10 \%)$, dan skala 4 sebanyak 1 responden $(10 \%)$.

Dari ketiga kelompok perlakuan tersebut frekuensi nilai maksimum yang ada pada masing-masing kelompok paling banyak ada pada skala 5 dengan berbagai jenis keluhan yang ada. Skala 5 menunjukkan kondisi nyeri pasien setara dengan tingkat nyeri diantara nyeri ringan hingga pada nyeri yang hebat (Kersten, White dan Tennant, 2014). Distribusi subyek penelitian berdasarkan Visual Analoge Scale sesudah terapi pada Kelompok I Terapi Akupunktur didapatkan data sesudah terapi nilai maksimum skala nyeri adalah skala 1 sebanyak 5 responden $(50 \%)$ dan skala 0 sebanyak 2 responden (20\%). Pada pengukuran skala nyeri sesudah terapi akupunktur terdapat $20 \%$ responden terbebas dari keluhan nyeri musculoskeletal yang memiliki skala nyeri 0. Dari pada Kelompok II didapatkan data sesudah pemberian Korean Hand Therapy nilai maksimum skala nyeri adalah skala 0 sebanyak 6 responden (60\%). Pada pengukuran skala nyeri sesudah pemberian Korean Hand Therapy terdapat $60 \%$ responden terbebas dari keluhan nyeri musculoskeletal dengan skala nyeri 0. Dari data Kelompok III sesudah pemberian Kombinasi Terapi Akupunktur dan Korean Hand Therapy nilai maksimum skala nyeri adalah skala 1 sebanyak 6 responden $(60 \%)$. Pada pengukuran skala nyeri sesudah 
pemberian Kombinasi Terapi Akupunktur dan Korean Hand Therapy terdapat $40 \%$ responden terbebas dari keluhan nyeri musculoskeletal dengan skala nyeri 0 .

$$
\text { Pada Kelompok I Terapi }
$$
Akupunktur, Kelompok II Korean Hand Therapy dan Kelompok III Kombinasi Terapi Akupunktur dan Korean Hand Therapy, pemberian terapi dapat memperbaiki perubahan skala nyeri yang dialami responden. Berdasarkan data statistik diatas pemberian tindakan tersebut memberikan hasil yang siginifikan menurunkan skala nyeri pada responden dengan nyeri musculoskeletal. Pada berbagai kasus keluhan nyeri musculoskeletal, terapi akupunktur dapat digunakan untuk mengurangi nyeri yang dirasakan dengan teknik myofascial pada area trigger point. Efek yang ditimbulkan dari penusukkan jarum akupunktur tersebut adalah untuk meningkatkan mikrosirkulasi, peningkatan di betaendorphin dan penurunan kortisol (Dunning et al., 2014).

Tabel 1. Distribusi Visual Analoge Scale (VAS) Responden Sebelum dan Sesudah Terapi

\begin{tabular}{|c|c|c|c|c|c|}
\hline \multicolumn{6}{|c|}{ VAS sebelum Perlakuan } \\
\hline & & Frequency & Percent & $\begin{array}{c}\text { Valid } \\
\text { Percent }\end{array}$ & $\begin{array}{c}\text { Cumulative } \\
\text { Percent }\end{array}$ \\
\hline \multirow{9}{*}{ Valid } & 4 & 1 & 3.3 & 3.3 & 3.3 \\
\hline & 5 & 14 & 46.7 & 46.7 & 50.0 \\
\hline & 6 & 4 & 13.3 & 13.3 & 63.3 \\
\hline & 7 & 4 & 13.3 & 13.3 & 76.7 \\
\hline & 8 & 4 & 13.3 & 13.3 & 90.0 \\
\hline & 9 & 1 & 3.3 & 3.3 & 93.3 \\
\hline & 10 & 2 & 6.7 & 6.7 & 100.0 \\
\hline & Total & 30 & 100.0 & 100.0 & \\
\hline & \multicolumn{5}{|c|}{ VAS sesudah Perlakuan } \\
\hline & & Frequency & Percent & $\begin{array}{c}\text { Valid } \\
\text { Percent }\end{array}$ & $\begin{array}{c}\text { Cumulative } \\
\text { Percent }\end{array}$ \\
\hline \multirow{6}{*}{ Valid } & 0 & 12 & 40.0 & 40.0 & 40.0 \\
\hline & 1 & 14 & 46.7 & 46.7 & 86.7 \\
\hline & 2 & 2 & 6.7 & 6.7 & 93.3 \\
\hline & 3 & 1 & 3.3 & 3.3 & 96.7 \\
\hline & 6 & 1 & 3.3 & 3.3 & 100.0 \\
\hline & Total & 30 & 100.0 & 100.0 & \\
\hline
\end{tabular}

Tabel 2. Distribusi perubahan Visual Analoge Scale (VAS) responden

\begin{tabular}{cccccc}
\hline \multicolumn{5}{c}{ Penurunan VAS } \\
\hline & Frequency & Percent & $\begin{array}{c}\text { Valid } \\
\text { Percent }\end{array}$ & Cumulative Percent \\
\hline \multirow{4}{*}{ Valid } & 2 & 2 & 6.7 & 6.7 & 6.7 \\
& 3 & 1 & 3.3 & 3.3 & 10.0 \\
& 4 & 6 & 20.0 & 20.0 & 30.0 \\
& 5 & 10 & 33.3 & 33.3 & 63.3
\end{tabular}




\begin{tabular}{ccccc}
6 & 4 & 13.3 & 13.3 & 76.7 \\
7 & 4 & 13.3 & 13.3 & 90.0 \\
8 & 2 & 6.7 & 6.7 & 96.7 \\
10 & 1 & 3.3 & 3.3 & 100.0 \\
\hline Total & $\mathbf{3 0}$ & $\mathbf{1 0 0 . 0}$ & $\mathbf{1 0 0 . 0}$ & \\
\hline
\end{tabular}

Tabel. 3 Uji Normalitas

\begin{tabular}{|c|c|c|c|c|c|c|c|}
\hline \multirow{6}{*}{$\begin{array}{l}\text { Penurunan } \\
\text { VAS }\end{array}$} & \multirow{2}{*}{$\begin{array}{c}\text { Jenis Terapi } \\
\text { Kelompok } \\
\text { Perlakuan }\end{array}$} & \multicolumn{3}{|c|}{ Kolmogorov-Smirnov $^{\mathrm{a}}$} & \multicolumn{3}{|c|}{ Shapiro-Wilk } \\
\hline & & Statistic & df & Sig. & Statistic & df & Sig. \\
\hline & $\begin{array}{l}\text { Korean Hand } \\
\text { Terapi }\end{array}$ & .242 & 10 & .099 & .924 & 10 & .389 \\
\hline & Korean Hand & & & & & & \\
\hline & $\begin{array}{l}\text { Terapi dan } \\
\text { Akupunktur }\end{array}$ & .230 & 10 & .143 & .927 & 10 & .421 \\
\hline & Akupunktur & .200 & 10 & $.200^{*}$ & .929 & 10 & .438 \\
\hline
\end{tabular}

\section{PEMBAHASAN}

Titik akupunktur dapat menghantarkan listrik lebih cepat dibanding area yang bukan titik akupunktur, hal ini karena titik akupunktur memiliki sel aktif listrik dengan sifat tahanan listrik rendah dan konduktifitas listriknya tinggi dibandingkan area yang bukan titik akupunktur. Pada reaksi reflek inflamasi lokal karena adanya penusukkan jarum akupunktur terjadi mikro trauma yang menyebabkan iritasi sel sehingga terjadi pelepasan bahanbahan kimiawi bradikinin dan prostaglandin yang akan mengaktivasi potensial membran sel.

Lokasi titik akupunktur yang berada di sekitar ujung saraf dan pembuluh darah akan memperbesar respon pelepasan bahan kimia tersebut (Saputra, 2009). Dengan adanya penusukkan pada titik akupunktur di seluruh bagian tubuh dapat mempengaruhi perasaan nyeri yang dialami responden. Secara menyeluruh pada ketiga kelompok perlakuan hasil akhir pengukuran Visual Analoge Scale mengalami penurunan skala nyeri, meskipun dalam grafik pertengahan terapi terdapat 4 responden mengalami peningkatan skala nyeri.

Berdasarkan hasil wawancara terhadap responden, kondisi nyeri pasien meningkat setelah pasien melakukan aktivitas fisik berlebihan. Hasil penelitian ini sangat erat dengan teori yang disampaikan oleh Middlesworth (2007) kerja otot yang digunakan secara berlebihan menyebabkan kelelahan dan gangguan muskuloskeletal. Pekerjaan yang berkaitan dengan kekuatan dan kemampuan tubuh dalam teknik mengangkat beban berat, pengulangan gerakan yang sama selama 30 detik dan postur tubuh yang tidak nyaman saat bekerja.

Selain itu secara fisiologis proses degenaratif akan mempengaruhi penurunan aliran darah ke otot secara bersamaan. Pada hasil distribusi responden berdasarkan usia usia pertengahan yaitu antara 45-59 tahun sebanyak 18 responden yang mengalami nyeri musculoskeletal. Sehingga dapat disimpulkan penurunan kekuatan otot seseorang karena adanya 
penurunan jumlah oksigen, nutrisi, dan energi yang tersedia untuk otot. Penurunan suplai oksigen, nutrisi, dan energi juga dipengaruhi oleh degenerasi serat otot rangka. Penurunan massa tonus dan kekuatan otot menyebabkan otot lebih menonjol di area ekstremitas sehingga bentuk otot menjadi kecil dan lemah (Brunner \& Sudarth, 2002).

Berdasarkan hasil distribusi jenis keluhan responden Kelompok I, II dan III terkait nyeri musculoskeletal antara lain nyeri bahu, nyeri pinggang, nyeri lutut, nyeri tumit, nyeri betis, nyeri telapak kaki. Frekuensi terbanyak ada pada jenis keluhan nyeri lutut sebanyak $30 \%$. Indikasi terapi akupunktur dapat digunakan untuk nyeri muskuloskeletal, gangguan sistem saraf, gangguan respirasi, meningkatkan imunitas tubuh, gangguan peradangan di mata, gangguan fungsional mulut, nyeri yang berkaitan dengan pencabutan gigi, peradangan kronis, gangguan di sistem gastrointestinal, dan arthritis area sendi (Saputra, 2005).

Berdasarkan hasil penelitian pada kelompok I Terapi Akupunktur serta kelompok III Kombinasi Terapi Akupunktur dan Korean Hand Therapy menunjukkan penurunan nyeri yang signifikan, bahkan menunjukkan hasil setelah dilakukan terapi pada Kelompok I sebanyak $20 \%$ pasien memiliki skala nyeri 0 , sedangkan Kelompok III sebanyak $40 \%$ pasien memiliki skala nyeri 0 .

Dalam teori neuro akupunktur, mekanisme prinsip kerja akupunktur analgesia melalui aktivasi modulasi nyeri transmisi neural ke otak dengan cara menekan transmisi dan persepsi rangsangan nyeri darti penusukkan jarum akupunktur pada level yang berbeda dari sistem saraf pusat. Akupunktur analgesia dengan cara melakukan stimulasi saraf dengan diameter kecil dari jarum akupunktur yang ditusukkan di jaringan otot kemudian terjadi reaksi pengiriman pesan dari impuls saraf ke medula spinalis, diteruskan ke medulla spinalis, mesensefalon, komplek pituitari hipothalamus. Rangsangan ke area tersebut dapat melepaskan neurotransmitter (endorfin dan monoamin) menghambat pesan nyeri yang datang (Kawakita dan Okada, 2014).

Sedangkan data lain pada kelompok II Korean Hand Therapy menunjukkan penurunan nyeri yang signifikan, bahkan menunjukkan hasil setelah dilakukan terapi sebanyak $60 \%$ pasien memiliki skala nyeri 0 . Hal ini karena adanya aliran darah yang dikirim ke tangan oleh arteri radialis dan ulnaris. Lengkungan palmar yang dangkal dan dalam menghubungkan kedua area ini di telapak tangan, dan cabang lebih lanjut menuju ke arteri digital palmaris dan arteri metacarpal palmaris ke jaringan jari. Vena superfisial tangan termasuk vena digital dorsal dan palmar dan vena cephalic. Vena dalam tangan termasuk lengkung vena palmar superior dan dalam, dan vena metacarpals palmar dan dorsal.

Selain itu tiga saraf yang berhubungan dengan persarafan tangan membantu sistem tersebut mengatur fungsi motorik dan sensorik ke tangan. Pembuluh limfatik membentuk pleksus subkutan yang kaya di tangan. Limfatik mengalirkan sisi radial tangan dan berakhir di aksila. Sisi ulnaris tangan berada di kelenjar supratrochlear di sekitar siku (Yajuan Wang, 2009).

Berdasarkan analisa data pada Kelompok I Terapi Akupunktur, 
Kelompok II Korean Hand Therapy dan Kelompok III Kombinasi Terapi Akupunktur dan Korean Hand Therapy menunjukkan hasil signifikansi $>0,05$ sehingga dapat disimpulkan Ho diterima, Ha ditolak artinya tidak ada perbedaan metode terapi dalam mengurangi nyeri. Sehingga diantara ketiga kelompok perlakuan tersebut tidak ada 1 kelompok yang paling efektif digunakan untuk mengatasi nyeri muskulokeletal. Ketiga kelompok tersebut memiliki hasil yang sama rata dalam penanganan nyeri musculoskeletal, meskipun dari data responden hasil pengukuran skala nyeri menunjukkan data signifikan.

\section{KESIMPULAN DAN SARAN}

Karakteristik subyek penelitian pada pasien lansia yang mengalami nyeri muskuloskeletal pada penelitian ini berdasarkan distribusi jenis keluhan adalah nyeri lutut sebanyak $30 \%$, berdasarkan distribusi usia paling banyak rentang usia 45-59 tahun sebanyak $45 \%$, berdasarkan distribusi jenis kelamin paling banyak perempuan sebanyak $70 \%$.

Efek teknik terapi akupunktur pada pasien lansia yang mengalami nyeri muskuloskeletal setelah dilakukan terapi pada skala 1 sebanyak 5 responden $(50 \%)$ dan skala 0 sebanyak 2 responden (20\%).

Efek teknik Korean Hand Therapy pada pasien lansia yang mengalami nyeri musculoskeletal setelah dilakukan terapi pada skala 1 sebanyak 3 responden (30\%), skala 0 sebanyak 6 responden $(60 \%)$.

Efek teknik Kombinasi terapi akupunktur dan Korean Hand Therapy pada pasien lansia yang mengalami nyeri muskuloskeletal setelah dilakukan terapi pada skala 1 sebanyak
6 responden (60\%) dan skala 0 sebanyak 4 responden $(40 \%)$.

Pada penelitian ini tidak ada metode yang paling efektif untuk mengatasi nyeri muskuloskeletal tidak ada perbedaan antara Kelompok Terapi Akupunktur, Kelompok Korean Hand Therapy maupun Kelompok Kombinasi terapi akupunktur dan Korean Hand Therapy. Ketiganya sama-sama dapat menurunkan skala nyeri, tetapi hasil data tidak menunjukkan perbedaan yang signifikan.

Rekomendasi dari hasil penelitian ini metode Terapi Akupunktur maupun Korean Hand Therapy dapat digunakan untuk mengatasi keluhan nyeri musculoskeletal dengan mempertimbangkan kondisi pasien apabila tidak memungkinkan dilakukan dengan menggunakan titik akupunktur tubuh, dapat menggunakan metode Korean Hand Therapy dengan menggunakan titik akupunktur yang ada di tangan.

\section{DAFTAR RUJUKAN}

Abdulla, A. N.Adams, M.Bone. (2013). Guidance on the management of pain in older people Age and ageing. Oxford Journals University Press on behalf of the British Geriatrics Society. Age and Ageing 2013; 42: i1-i57. doi: 10.1093/ageing/afs 200

Arovah Intan Novita. (2010). DasarDasar Fisioterapi pada Cidera Olahraga. Jurnal Ilmu Keolahragaan Fakultas Ilmu Keolahragaan Universitas Negeri Yogyakarta

Brunner \& Suddarth. (2002). Buku Ajar Keperawatan Medikal Bedah, alih bahasa: Waluyo Agung., 
Yasmin Asih., Juli., Kuncara., I.made karyasa, EGC, Jakarta.

Dunning, J., Butts, R., Mourad, F., Young, I., Flannagan, S., dan Perreault, T. (2014). Dry needling: a literature review with implications for clinical practice guidelines1. Physical Therapy Reviews, 1-14. doi:10.1179/108331913X138442 45102034.

Hofstede, S. N., Marang-van de Mheen, P. J., Wentink, M. M., Stiggelbout, A. M., VleggeertLankamp, C. L. a, Vliet Vlieland, T. P. M., \& van Bodegom-Vos, L. (2013). Barriers and facilitators to implement shared decision making in multidisciplinary sciatica care: a qualitative study. Implementation Science: $\quad$ IS, $8(1), \quad 95$. doi:10.1186/1748-5908-8-95.

Kawakita, K. dan Okada, K. (2014). Acupuncture therapy: mechanism of action,efficacy , and safety: a potential intervention for psychogenic disorders. Bio Psycho Social Medicine 2014, 8:4 doi:10.1186/1751-0759-8-4.

Kersten, P., White, P. J., \& Tennant, A. (2014). Is the pain visual analogue scale linear and responsive to change ? An exploration using Rasch analysis. PloS One, 9(6), e99485. doi:10.1371/journal.pone.009948 5.

Matzkin, E., dan Paci, G. M. (2014). Musculoskeletal Health in
Women, 1-13. doi:10.1007/9781-4471-4712-1.

Middlesworth, M. (2007). A Step By Step Guide Rapid Entire Body Assessment (REBA). Ergonomics Inc. Plus: www.ergo-plus.com Diakses: 21 April 2014

Saputra, Koosnadi dan Syarif Sudirman. (2009). Akupunktur untuk Nyeri dengan Pendekatan Neurosain. Jakarta: CV.Sagung Seto.

Sun Peilin. (2011). The Treatment of Pain With Chinese Herbs and Acupuncture. Elsevier. China

Veerapen, K., Wigley, R. D., dan Valkenburg, H. (2007). Musculoskeletal pain in Malaysia: A COPCORD survey. Journal of Rheumatology, 34, 207-213.

Woolf, Anthony D. (2010). Musculoskeletal Pain: Incidence , Prevalence And Impact on Healthy Ageing. Royal Cornwall Hospital, Truro dan Peninsula College of Medicine and Dentistry, UK.

Yajuan Wang. (2000). Micro Acupuncture in Practice. USA: Elsevier 